\title{
Expressions of authoritarianism in Facebook before the salience of news about crime in Peru
}

\section{Expresiones de autoritarismo en Facebook ante la exposición a noticias sobre delincuencia en Perú}

\section{Expressões de autoritarismo no Facebook ante o destaque de notícias sobre delitos no Peru}

\author{
José Román ${ }^{1}$, ORCID 0000-0002-9787-7356 \\ Agustín Espinosa ${ }^{2}$, ORCID 0000-0002-2275-5792 \\ Harry M. Lewis ${ }^{3}$, ORCID 0000-0002-2504-4611 \\ ${ }^{12}$ Pontificia Universidad Católica del Perú \\ ${ }^{3}$ University of Sussex, England
}

\begin{abstract}
Under a context of public insecurity, the present study aims to analyse comments expressed in news about criminal acts published on the web pages of the main national newspapers during 2015. Comments were subject to content analysis and two analytical axes identified: (a) The expression of authoritarian beliefs and the implications of these beliefs for perceptions of offenders, and (b) a lack of trust in the public institutions of justice and its link with authoritarian response to criminality. The analysis of comments reveals a strong tendency towards endorsements of violent actions in dealing with crime supported by an authoritarian ideology. It was also found that distrust in the public institutions of justice is linked to support for extreme measures in order to eliminate the perceived threat. Limitations and suggestions for further research are discussed.
\end{abstract}

Keywords: authoritarianism; authoritarian response; trust on the public institutions; social networks; violence.

Resumen: En un contexto de inseguridad social, el presente estudio tiene como objetivo analizar los comentarios expresados ante noticias sobre delincuencia publicadas durante el 2015 en las redes sociales de los principales diarios de circulación nacional en el Perú. Los comentarios fueron sujetos a un análisis de contenido y se identificaron dos ejes analíticos: (a) la expresión de creencias autoritarias y las implicancias de dichas creencias en la percepción de los delincuentes, y (b) la falta de confianza en las instituciones públicas de justicia y seguridad, y su relación con la respuesta autoritaria ante la criminalidad. El análisis de los comentarios revela una fuerte tendencia hacia el apego a acciones violentas de control social como forma de enfrentar la criminalidad, lo que parece asociado a una ideología de tipo autoritario. También se aprecia que la desconfianza hacia las instituciones públicas de justicia y seguridad está relacionada con las medidas que estas utilicen para eliminar las amenazas percibidas. Se discuten las limitaciones y sugerencias para futuras investigaciones.

$(c)$ EY

This work is under a Creative Commons Attribution 4.0 International License 
Palabras clave: autoritarismo; respuesta autoritaria; confianza en instituciones públicas; redes sociales; violencia.

Resumo: Em um contexto de insegurança cidadã, o presente estudo tem como objetivo analisar os comentários expressados frente a notícias sobre ações delitivas publicadas durante o ano de 2015 nas redes sociais dos principais jornais de circulação nacional do Peru. Os comentários foram sujeitos a uma análise de conteúdo com dois eixos analíticos identificados: (a) a expressão de crenças autoritárias e as implicações dessas crenças na percepção acerca dos delinquentes, e (b) a falta de confiança nas instituições públicas de justiça e segurança, e a sua relação com a resposta autoritária ante a criminalidade. A análise dos comentários mostra uma forte tendência em favor de ações violentas de controle social como forma de enfrentar a criminalidade, o que parece associado a uma ideologia do tipo autoritário. Também se observa que a falta de confiança nas instituições públicas de justiça e segurança cidadã está associada com as medidas de controle que essas utilizam para eliminar as ameaças percebidas. Limitações e sugestões para pesquisas no tema são discutidas.

Palavras-chave: autoritarismo; resposta autoritária; confiança nas instituições públicas; redes sociais; violência.

Received: 01/20/2021

Accepted: 05/19/2021

How to cite:

Román, J., Espinosa, A., Lewis, H. M. (2021). Expressions of authoritarianism in Facebook before the salience of news about crime in Peru. Ciencias Psicológicas, 15(2), e-2439. doi: https://doi.org/10.22235/cp.v15i2.2439

Correspondence: Agustín Espinosa, Pontificia Universidad Católica del Perú. E-mail:
agustin.espinosa@pucp.pe

\section{The perception of insecurity and fear of crime: implications for the digital age}

Within the field of Social Psychology, there are two interrelated but qualitatively distinct social phenomena which have been studied: the perception of insecurity and the fear of crime. The perception of insecurity refers to the fear of crime in the abstract, as a concern about crime as a social problem (Vozmediano, San Juan \& Vergara, 2008). It is a mental representation, often socially reproduced, about the extent to which criminality poses a threat generally, and can vary according to the social group to which one belongs. Fear of crime, on the other hand, is an emotional response to possible victimisation based on an estimate of personal risk (Covington \& Taylor, 1991; Ferraro, 1995) and results from exposure to and internalisation of information obtained from the environment, political speeches and media accounts of crime and criminality (Ferraro, 1995; Vozmediano et al., 2008). 
The fear of crime can have important psychological and social consequences. Research suggests that a high fear of crime can generate distrust, lower levels of empathy and even cause anxiety and depression in those who experience it (Stafford, Chandola \& Marmot, 2007). Further to this, a fear of crime has been shown to affect individuals' relationship with the physical environment, with those experiencing a higher fear of crime more likely to perceive environments as potentially dangerous and thus avoid them (Ruiz \& Turcios, 2009). Finally, fear of crime has also been shown to have an impact on individuals' attitudes, generating increased levels of support for punitive measures and violent action directed against individuals perceived as delinquent, such as the use of corporal punishment as a means of 'correction' (Armborst, 2017).

In recent years, Peru has experienced a rise in citizens' perceptions of insecurity, with national survey data showing that over $85 \%$ of the population do not feel safe within their city, despite only $35 \%$ of respondents reporting have experienced crime directly (Instituto Nacional de Estadística e Informática [INEI], 2015). Research has shown that this somewhat paradoxical relationship between victimisation and the perception of insecurity is relatively common, with those who have not been a direct victim of crime reporting a generally higher fear of crime when compared with those who have been victims (Hale, 1996). Whilst the precise psychological and environmental factors which account for a fear of crime are contested (e.g. Farrall, Gray \& Jackson, 2007), research has shown that fear of crime is significantly impacted by news media coverage of stories relating to crime and criminality (Vozmediano et al., 2008), as well as the testimony of close others who have been direct victims (Ferraro, 1995). As such, an individual's fear of crime is not necessarily representative of the risk that that individual faces in relation to being a victim of crime (Hale, 1996; Redondo \& Pueyo, 2007; Vozmediano, San Juan \& Vergara, 2009).

The recent revolution in the way we communicate has provided individuals with new and more complex ways of accessing information of all kinds (Morales, 2004). The internet functions as a freely accessible space in which information can be obtained in a fast and practical way (Rial, Gómez, Braña \& Varela, 2014). In addition, the internet has facilitated a growth in virtual connectivity, whereby individuals can be 'connected' with a vast number of others without the need for physical proximity, thereby transcending the geographical and territorial limitations that existed pre-internet (Lara, 2008). Of particular interest is the way in which the transmission of information has changed in relation to the proliferation of social media and social networking sites (Bergström \& Jervelycke, 2018), especially in relation to stories relating to crime and criminality. Historically such stories were encountered through the traditional news media outlets such as TV, radio and newspapers. This has changed significantly with the rise of social networking sites such as Facebook, Instagram and Twitter. The global reach of these sites has led to their widespread adoption by mainstream news media outlets and, as such, individuals' exposure to news stories relating to crime is not only instantaneous, but also socially mediated, allowing for an unprecedented level of interaction through story sharing and public commenting (Holton, Coddington, Lewis \& Gil de Zúñiga, 2015). 
The relationship between the growth of socially mediated accounts of crime and criminality with the fear of crime and perception of insecurity is underexplored. As a speculative hypothesis, it is assumed that the experience of the latter is related to the proliferation of the former - a result of the speed and scope of the dissemination of such stories. This process is further enhanced through individuals' increasing exposure to unmediated personal testimonies relating to the direct experience of crime, giving the impression that crime is more pervasive than it actually is.

\section{Threat Perception, Right Wing Authoritarianism and Attitudes towards Human Rights}

As a response to the perception of threat, the fear of crime is linked with both danger avoidance and danger mitigation behaviours (Florack, Piontkwoski, Rohmann, Balzer \& Perzig, 2003). In this respect, several studies have reported that the fear of crime can manifest itself in high levels of authoritarian behaviour and attitudes (Crowson, Debacker \& Thoma, 2006; McCann, 1999; Sales, 1973). This latter aspect, related to the expression of authoritarian attitudes, has become an important focus of social psychological research (Feldman, 2003). Embedded within a broader ideology, authoritarianism forms a socially shared mental framework for understanding the social world which underpins opinions and attitudes towards politics, social structures and other prescriptive dimensions encompassing the make-up of society (Jost, Federico \& Napier, 2009). Within social psychology, much of the research looking at authoritarian ideology has been through the lens of right-wing authoritarianism (RWA; Altemeyer, 1993). On this model, authoritarianism is principally manifested through the expression of three broad attitudes: (1) a high level of submission to the authorities legitimized by the society in which one lives; (2) a manifestation of aggression against persons who act against those authorities; and (3) a high level of adherence to the dominant social norms embedded in the society in which one lives (Altemeyer, 1993).

There is a wealth of research exploring the interaction between authoritarian attitudes and the fear of crime, particularly in relation to the endorsement of punitive policies directed at those responsible for committing criminal acts. It has been shown that authoritarian individuals are more sensitive to perceiving threats, be they real or symbolic, to their perception of the established social order (Etchezahar, 2012; McCann, 2008). This sensitivity is the foundation of the phenomenon known as 'authoritarian response', defined as a set of hostile and inflexible attitudes and behaviours directed mainly towards groups that are perceived as threatening the established social order (Oesterreich, 2005; Rottenbacher \& De la Cruz, 2012). When present, the authoritarian response is manifested through an endorsement of state sanctioned punitive measures of punishment as a fair and adequate solution to deviant behaviour (Stenner, 2005). Such measures can include the use of capital punishment (McCann, 2008), physical violence (Benjamin, 2006) and, in more serious cases, support of social and political measures with the potential to undermine human rights (Amaya, Espinosa \& Vozmediano, 2011).

The support for campaigns, measures or actions advocating the use of violence against those who transgress the established social order can be viewed as an expression of collective attitudes. From a social perspective, collective attitudes are those that reflect the values endorsed by a group (Tyler \& Blader, 2003). In groups that share a high level of authoritarian attitudes, the authoritarian response is likely to arise in situations in which the established social order is threatened, resulting in negative attitudes and potential violence 
towards individuals perceived as potentially dangerous. This response is often rationalised through moral justification and a process of dehumanisation. Moral justification refers to a psychological mechanism in which action deemed normatively questionable are justified as necessary in contexts whereby the welfare of the group is threatened (Bandura, 1999). Through the re-classification of outgroups as inferior beings, the process of dehumanisation is a psychological mechanism which makes it easier to commit violent actions against members of that outgroup, as the quality of being a person has been dislodged thereby removing certain moral constraints on action (Bandura, 1999).

As outlined earlier, in Peru levels of public insecurity far exceed levels of victimisation. This imbalance, it is argued, is partly a response to media coverage and sensationalisation of issues relating to crime and criminality. Recent years have witnessed a rise in online campaigns directed at tackling criminality, the most representative of which is known as the "Chapa tu choro y déjalo paralítico" (Catch your thief and leave him paralysed). This movement encourages vigilante responses to criminality over engagement with the National Police and Judiciary (El Comercio, 2015a; BBC Mundo, 2015). This response has arisen out of a lack of confidence that many Peruvians feel with regard to the effectiveness of public institutions in dealing with crime - a belief that is largely supported by national statistics (Corporación Latinobarómetro, 2018). The Chapa tu Choro movement's online dissemination means that it has reached a wide audience within Peru, and allows for a high level of interaction through social media sharing of graphic videos and accounts of "vigilante justice', as well as comments from distant non-participants. As such, it provides a good opportunity to explore the interaction of perceived threat, fear of crime and RWA as contributing factors in the rejection, dehumanisation and punishment of those who violate the established social order. The present study utilizes content analysis of comments on news stories about criminal events published in the virtual pages of national newspapers of Peru during 2015. It focuses specifically on occurrences of dehumanization of offenders and the justification of physical violence as a legitimate means of justice; the development of negative attitudes towards human rights and support for capital punishment; and perceptions of the efficacy of public justice institutions.

\section{Method}

\section{Participants}

The sample was made up of users of the main virtual social networks used in Peru. In particular, the participants were those individuals who made comments in the police news publications that the national newspapers spread in their virtual pages and were accessible by Facebook.

Newspapers were selected for inclusion on the basis of their having active social media accounts with moderate to high engagement through Facebook. The potential for diversity in the editorial lines adopted by different newspapers was also taken into consideration, so that those chosen for inclusion are taken as representative of conservative, liberal, and populist positions on the issue in question. In total, five national newspapers were chosen: El Comercio, La República, Correo, Perú 21 and El Trome. 
In this way, the analysis of the results was not based on a certain number of participants, but on a set of comments expressed towards the news on Facebook during 2015. These comments were obtained from the news sections corresponding to criminal acts of the Facebook pages of national newspapers.

\section{Data collection and analysis}

Comments were collected and analysed in reverse chronological order, running backwards from December 2015 to January 2015. Analysis stopped at the point in which no new relevant information was discovered which allowed for the generation of new categories, in line with the saturation principle of qualitative research (Coolican, 2005; Salgado, 2007). In total, 144 comments were analysed on a total of 132 news reviewed.

Comments were compiled in image format, under a standardized format that allowed the corresponding registration of each comment. The images of the comments were ordered according to the numbering and corresponding date. In addition, it should be noted that the content analysis was carried out on the comments written by users of social networks, excluding publications or "tags" that were not related to the news contents.

Comments were analysed using the qualitative research technique of content analysis. Content analysis allows users to identify patterns of information through a systematic reading and coding of the textual content (Coolican, 2005; Salgado, 2007). For the purpose of this study, the information collected was analysed in four phases.

In order to facilitate review of the comments, prior to the analysis, comments collected in image format were transferred to a matrix in a word processor. All comments were then read and initially coded so as to enable an independent review of the comments by two of the researchers as a criterion for the quality of the analysis.

Firstly, the comments were coded according to the types of news story to which they referred. Three categories of representative story were identified: (1) stories in which criminal commit a crime successfully, (2) stories in which criminals were apprehended by the National Police of Peru (PNP), and (3) stories in which criminals were killed by the PNP during the process of committing the crime. As an important consideration, selected news were focused in robberies and assaults because there are common crimes.

Secondly, a preliminary analysis of the selected comments was carried out in order to identify themes or categories that could be delimited according to the discursive content found. Thirdly, the selected information was codified according to thematic categories which constituted the central themes of analysis. Finally, an integrated analysis was conducted in which the themes identified in stage 3 were subject to contextualisation within the parameters of the research aims (cf. Salgado, 2007).

\section{Ethical considerations}

All data used in the analysis is in the public domain and freely available, as such informed consent was neither required nor requested. Any information relating to the identity of the author of comments was removed prior to analysis (Gonzáles, 2002; Guevara, 2012). 


\section{Results and discussion}

In general, the comments analysed expressed a wide variety of positions. Among the most prominent were comments expressing aggressions of the authoritarian type, including references to killing or physically assaulting offenders. The second most prominent type of comments identified were those criticising the effectiveness of public institutions, especially the Judiciary, congress and the PNP. This investigation will critically consider these comments along two axes of analysis; firstly, the ways in which authoritarianism manifests through discourse and the implications for public perceptions of the offender figure will be discussed. Secondly, the link between fear of crime and distrust of public institutions in relation to the authoritarian dynamic manifested in the comments will be critically considered. It should be noted that the analysis axes represent a referential framework with which to facilitate a discussion of the results in an organized manner. However, in reality, the discourse expressed in the comments contained various integrated elements relating to authoritarianism, criticism of institutions and emotions, among others.

\section{Story type 1: The successful offender}

This type of story focuses on events in which the offender or offenders are successful in stealing something valuable from a person or entity without being caught. A significant number of the comments relating to this type of story appear to advocate retribution through physical violence or even death. To a lesser extent, commenters present proposals for legalistic punishments along with verbal attacks against the unknown offenders. Such commentary can be observed in the following comments (translated from Spanish):

"A headshot and the crime ends" (Comment in El Comercio on 11-21-2015);

"Citizens must kill them, that will be the only way to end so much garbage - get together and kill at least one per week" (Comment in El Trome on 07-10-2015);

"Cut off 1 finger and if they repeat, the whole hand" (Comment in El Trome on 08-30-2015);

"URGENT: death squads to end all this scourge" (Comment in El Trome on 09-18-2015).

Comments on stories relating to successful offenders also highlighted dissatisfaction with the public authorities in handling such crimes with many commenters encouraging the use of collectively administered justice as a potentially more effective means of dealing within offenders. These comments were especially noticeable in relation to their support for the Chapa tu Choro campaign. Positions endorsing collectively administered justice were often supported by negative comments concerning rehabilitative approaches to justice, suggesting instead that criminality is a fixed lifestyle.

"If the authorities do nothing, let's do it, let's take this criminal and give him just punishment, at the end, source all sheep to one" (Comment in La República on 05-08-2015);

"This is the justice in Peru, criminals have more protection than a good citizen, so CHAPA TU CHORO and smash him" (Comment in El Trome on 07-09-2015); 
"These blunders are no longer going to regenerate, they only serve to pollute society and they are proud to be thugs because many corrupt authorities are their inspiration. Chapa tu choro" (Comment in El Comercio on 04-09-2015).

From a psychosocial perspective, the expression of support for acts of aggression against offenders can be seen as a product of authoritarianist beliefs combined with a fear of crime. On this model, the acts of offenders as reported online by news agencies and individual testimonies are perceived by individuals as indicative of a broader social threat with the potential to destabilize the established social order. The authoritarian responses indicate a desire to remove this threat in order to maintain the existing social arrangement (Crowson et al., 2006; McCann, 1999; Sales, 1973).

Comments are suggestive of two principal ways in which the perceived threat can be removed: either through the death of the offenders, or through the legitimized use of violence as a corrective measure (Cohrs \& Asbrock, 2009; Etchezahar, 2012). This latter approach is linked to a separate but related psychological phenomenon: the dehumanisation of the offender figure as a means through which the use of violence can be morally justified (Bandura, 1999; Rodríguez, 2007). This process facilitates the construction of criminal actors as sub-human and thus outside of the existing normative moral framework and, as such, the use of violence against such individuals does not transgress these moral norms (Bandura, 1999; Bar-Tal, 1990). This process opens up the possibility for the rationalisation of violent acts towards criminals on the grounds that doing so contributes to the overall welfare of society - the use of violence is both justified and necessary in order to maintain the stability of society.

As already outlined, a number of comments express a lack of confidence in the effectiveness of the national agencies in dealing with criminality, particularly in relation to the work of the judiciary and the National Police. Such distrust is based on a perception of authorities as inefficient and/or indifferent to the problems relating to citizen security, resulting in feelings of resignation and a belief that these agencies are not allied in the citizenled fight against criminality (Mainwaring, 2006). The strength of this distrust was particularly noticeable in comments suggesting that the authorities' indifference was a result of collusion with criminals:

"Each curator knows the thieves from its jurisdiction, it goes without saying that police inefficiency is more than suspicious" (Comment in El Comercio on 07-10-2015);

"Now if the victim is going to make a complaint, he runs the risk of being imprisoned. If they catch criminals, they are charged for loot and are free to continue working" (Comment in $E l$ Comercio on 07-15-2015).

Such comments reflect findings from studies which show that between $70 \%$ and 80 $\%$ of the population of Peru express a distrust of the judiciary and other national institutions (Corporación Latinobarómetro, 2018; El Comercio, 2015b). This distrust is further manifested in comments which are critical of responses proposing non-violent alternative solutions to dealing with criminals: 
"... and where are all those who criticize the campaign chapa tu choro, what alternative do they propose? Crime continues to progress" (Comment in La República on 11-16-2015);

"Now that the sector will say that we must call the police and not take justice through our own hands ... more innocent lives must be lost ... I prefer that cemeteries be filled with undesirable rather than innocent" (Comment in El Comercio on 03-09-2015).

Such comments are indicative of a perspective in which all hope of traditional avenues of justice have been removed.

\section{Story type 2: The offender is apprehended by the police}

The second story type focuses on stories in which offenders have been captured either prior to, during or after carrying out a criminal act.

Comments on stories of this type reflect those found in story type 1: many comments are found to be promoting violence towards even the killing of those who participated in the criminal act. Interestingly, despite the apprehension of the offenders, many comments also express a negative view of the effectiveness of the public institutions responsible for dealing with criminality. The noticeable difference is that these comments predominantly focus on the work of the judiciary and criticisms of the approach to sentencing those that are caught. Further to this, alongside criticism of the judiciary, many comments criticised the work of Peru's prison system, expressing doubt its capacity to rehabilitate those caught and advocating instead for a more retributive approach to criminality:

"And they captured them alive? ... silver for the palace of injustice to be released around the corner, dead are in the ways that will be most useful for society" (Comment in La República on 06-08-2015);

"The punishment is not enough, you have to cut your thumbs" (Comment in La República on 09-09-2015);

"Congratulations to the cops, but please, why they didn't liquidate them. They will go out and do the same again" (Comment in El Trome on 12-30-2015);

"Hopefully right now our dear judiciary ... I have not put these blunders on the streets again ... Antiblots squad and point ...! Eliminate them!" (Comment in El Trome on 08-27-2015);

"That's why and much more catch your thieve and LEAVE IT PARALIZED!" (Comment in El Comercio on 04-09-2015).

This subtle transition of critical focus from the PNP and Judiciary to the Judiciary and penal system further reflects the high distrust of the public institutions to fulfil their function and effectively maintain social stability. Such distrust is not a recent phenomenon but is reflective of Peru's history of corruption and injustice (Corporación Latinobarómetro, 2018). Further to this, it has been found that there is a link between trust in public institutions and overall crime rates, suggesting that individual perception of institutional efficacy is related to levels of trust (Mainwaring, 2006). This is reflected in the following comments: 
"Hopefully they will not release them, our justice is one of the worst" (Comment in El Trome on 04-09-2015);

"More trapped suckers, more money for the judiciary" (Comment in La República on 02-092015);

"They can capture them, but then the Judiciary leaves them free in a few hours" (Comment in La República on 02-09-2015).

The above comments reveal a common theme in relation to dealing with criminality, with the vast majority of comments indicative of a demand for penalties delivered outside of the established legal framework and involving violence directed towards the offender. Such violence appears to serve one of two primary purposes: it can be used as a corrective means by which to deter criminals or as a means by which to reduce the population of criminals through extrajudicial killings thus preventing the possibility of future offences (McCann, 2008). Such comments support the idea that crime is perceived as more prolific than the data actually suggests, and thus extreme action is warranted in order to restore social order.

\section{Story type 3: The offender is killed by the police}

In this story type, the offenders are killed by the PNP, usually by being shot, during the committing of an offence.

Comments on these stories reinforce the notion that the death of the criminal is the most effective means through which to achieve justice. Often this is manifested through expressions of satisfaction and positive emotion with regards to the death of the offender. Interestingly, in opposition to story types 1 and 2, comments on type 3 stories express a greater degree of satisfaction with and recognition of the work carried out by the PNP in its fight against crime. However this is often balanced by further criticism of the judiciary, although configured in a different way to the criticisms found in story type 1 and 2 . Firstly, these criticisms suggest that, due to the ineffectiveness of the judiciary, the death of the criminals is the only alternative to reduce criminality and, secondly, there is concern expressed that the judiciary, in its favouring of criminals over true justice, will punish the police despite their commendable action in fighting against crime:

“One less scourge, brave police!” (Comment in La República on 25-08-2015);

"Applause for the policeman! Only in this way can we end this scourge of people" (Comment in La República on 25-08-2015);

"The only offender who does not commit a crime again is the dead offender" (Comment in El Comercio on 10-09-2015);

"I do not justify the violence, but it is impossible to endure that nobody does anything, prosecutors, corrupt judges..." (Comment in El Trome on 10-09-2015);

"Just one question: if three criminals attack me, I defend myself and kill one, the one who is imprisoned, is it me? That is the law or the judges are committed to criminals" (Comment in El Comercio on 10-09-2015); 
"Well, the bad thing that the prosecution and some NGOs will ask for jail for the homicidal police ... Pfff on behalf of 'the famous human rights"' (Comment in La República on 10-092015);

"The dog is dead, the rabies is dead, the kid is dead, the work of prosecutors and judges is over, it is a time saver for everyone" (Comment in El Comercio on 10-09-2015).

Such expressions of satisfaction and positive emotionality can be interpreted as expressions of support for the violation of the fundamental human rights of individuals engaged in crime as, once again, the authoritarian response is manifested through support for the need to eliminate the perceived threat to societal order (McCann, 2008; Oesterreich, 2005). Once again, we can also see the process of dehumanisation occurring within these comments, particularly in relation to terms such as "the dog" and "scourge". Furthermore, there is a noticeable shift in in stories of this type, whereby commenters move from advocacy for the death of offenders to a celebration of the fact that the offender has been killed. This is again interesting from an authoritarian perspective, as it further supports the notion that fear of crime can lead to the degeneration of support for human rights. Furthermore, expressions of concern and outrage at the possibility that those who are responsible for the death of the criminal might have to face some form of criminal prosecution themselves. Such comments serve to further enhance perceptions of the judiciary as the enemies of justice by emphasising their retaliation against those that they perceive to be the true administers of justice and restorers of social order - in this case the PNP.

\section{Conclusions and limitations}

Conclusions drawn from the preceding analysis are as follows:

- $\quad$ Stories relating to crime and criminality seems to reinforce a perception of the world as highly dangerous. The majority of comments analysed support findings regarding the relationship between a fear of crime and authoritarian responses to crime, most notably in relation to expressions of support for violence directed towards offenders and, in extreme cases, the killing of criminals as a justifiable response to criminality (Altemeyer, 1993; Cohrs \& Asbrock, 2009; Crowson et al., 2006; Oesterreich, 2005; Sales, 1973).

- The authoritarian attitudes exemplified through support for vigilante violence are often supported through reference to the failure of the institutions responsible for the administration of justice to effectively carry out their work. That this is reflective of a broader perspective within Peru is supported by research showing high levels of distrust in these institutions (Corporación Latinobarómetro, 2018; Mainwaring, 2006). As such, commenters view vigilante justice as the only option for adequately dealing with the perceived threat. 
- Comments suggest that the Chapa tu choro movement is viewed as a legitimate means by which to execute vigilante justice and an effective alternative to reducing or eliminating the perceived threat (Stenner, 2005).

- On the other hand, this research is configured as a scientific approach to the analysis of data in social networks with respect to social and political contexts of psychological interest. Thus, in the future, user interactions regarding current issues or relevant media campaigns can be sought not only from Facebook and Twitter, but also from comments on YouTube, Instagram, TikTok and other similar networks.

- In the same vein, this type of research could serve to create quantitative measurement tools that would allow the results obtained to be generalised from a more precise statistical analysis. It would also be useful to measure other constructs such as users' level of participation in social networks, as well as their preferences and orientations in the social, cultural and even economic spheres.

Limitation and suggestion for further study are as follow:

- The focus on social networks as the source of the data for this study limits the generalisability of the study to those who interact with stories regarding crime and criminality.

- All comments collected were chosen precisely because they were published on social networks. Future research could focus on other forms of digital participation in social networks, as individuals' opinions are not necessarily expressed only through comments.

- In this regard, interaction on social networks could also be measured and analysed through the number of likes or upvotes received on a comment or reply; number of comments per post; and/or the number of different users interacting on the same post, for example.

As a final reflection, it is important to note that citizens' perception of public institutions as corrupt, inefficient or even indifferent to citizens can lead to support for more authoritarian leadership in establishing a sense of security (Mainwaring, 2006). Sadly, the recent history of Peru is marked by a succession of authoritarian governments who have caused great harm to the population, including significant violations of human rights (Espinosa \& Velázquez, 2015). It is the position of the authors that violence, however and by whoever expressed, does not constitute a real solution to the problem of crime, but is rather a part of a vicious cycle of hostility between both victims and perpetrators. A better alternative would be to approach the issue from the perceptive of an education for peace, whereby social relations are enhanced through spreading a greater awareness of the prejudices and stereotypes that affect the many marginalised groups in Peruvian society (Echevarría, Bernal, Murcia, González \& Castro, 2016). 


\section{References}

Altemeyer, B. (1993). Nacionalismo y Autoritarismo de Derechas entre legisladores americanos. Psicología Política, 7, 7-18.

Amaya, L; Espinosa, A. \& Vozmediano, L. (2011). Relaciones entre el Miedo al delito y el Autoritarismo de Derecha en estudiantes universitarios de Lima-Perú. Boletín de Psicología, 103, 7-28.

Armborst, A. (2017). How Fear of Crime Affects Punitive Attitudes. European Journal of Criminal Policy Research, 23, 461-481. doi: https://doi.org/10.1007/s10610-0179342-5

Bandura, A. (1999). Moral Disengagement in the Perpetration of Inhumanities. Personality and Social Psychology Review, 3(3), 193-209. doi: https://doi.org/10.1207/s15327957pspr0303_3

Bar-Tal, D. (1990). Causes and Consequences of Delegitimization: Models of Conflict and Ethnocentrism. Journal of Social Issues, 46(1), 65-81. doi: https://doi.org/10.1111/j.1540-4560.1990.tb00272.x

BBC Mundo. (September 16, 2015). “Chapa tu choro”, la peligrosa campaña que busca combatir la delincuencia en Perú. Retrieved from http://www.bbc.com/mundo/noticias/2015/09/150911_peru_delincuencia_chapa_chor o_ilm

Benjamin, A. J. Jr. (2006). The relationship between right-wing authoritarianism and attitudes toward violence: Further validation of the Attitudes toward Violence Scale. Social Behavior and Personality: An International Journal, 34(8), 923-926. doi: https://doi.org/10.2224/sbp.2006.34.8.923

Bergström, A. \& Jervelycke, M. (2018). News in Social Media. Incidental consumption and the role of opinion leaders. Digital Journalism, 5(6), 583-598. doi: https://doi.org/10.1080/21670811.2018.1423625

Cohrs, J. \& Asbrock, F. (2009). Right-wing authoritarianism, social dominance orientation and prejudice against ethnic groups threatening and competitive. European Journal of Social Psychology, 39(2), 270-289. doi: https://doi.org/10.1002/ejsp.545

Coolican, H. (2005). Métodos de Investigación y Estadística en Psicología. México: Manual Moderno.

Corporación Latinobarómetro. (2018). Informe Latinobarómetro 2018. Retrieved from http://www.latinobarometro.org/latdocs/INFORME_2018_LATINOBAROMETRO.p df

Covington, J. \& Taylor, R. (1991). Fear of crime in urban residential neighborhoods: Implications of between -and whitin- neighborhood sources for current models. The Sociological Quaterly, 32(2), 232-249. doi: https://doi.org/10.1111/j.15338525.1991.tb00355.x

Crowson, M., Debacker, T. \& Thoma, S. (2006). The Role of Authoritarianism, Perceived Threat, and Need for Closure or Structure in Predicting Post-9/11 Attitudes and Beliefs. The Journal of Social Psychology, 146(6), 733-750. doi: https://doi.org/10.3200/SOCP.146.6.733-750 
Echevarría, C., Bernal, J., Murcia, N., González, L. \& Castro, L. (2016). Contribuciones de la Institución Educativa al Postconflicto: Humanizarte, una propuesta pedagógica para la construcción de la paz. Cuadernos de Administración, 28(51), 159-187. doi: https://doi.org/10.11144/Javeriana.cao28-51.ciep

El Comercio. (September 13, 2015a). Chapa tu choro: una historia violenta. Retrieved from http://elcomercio.pe/peru/pais/chapa-tu-choro-historia-violenta-opinion-noticia1840570

El Comercio. (September 24, 2015b). Tremenda desconfianza: opinión ciudadana sobre instituciones. Retrieved from http://elcomercio.pe/politica/actualidad/tremendadesconfianza-opinion-ciudadana-sobre-instituciones-noticia-1842421

Espinosa, A. \& Velázquez. T. (2015). Community Psychology and the Need for Community Participation in Peru. Journal of Prevention and Intervention in the Community, 43(4), 235-237. doi: https://doi.org/10.1080/10852352.2014.973299

Etchezahar, E. (2012). Las dimensiones del autoritarismo: Análisis de la escala de autoritarismo del ala de derechas (RWA) en una muestra de estudiantes universitarios de la Ciudad de Buenos Aires. Revista Psicología Política, 12(25), 591-603.

Farrall, S., Gray, E. \& Jackson, J. (2007). Theorising the Fear of Crime: The Cultural and Social Significance of Insecurities about Crime. Experience \& Expression in the Fear of Crime Working Paper, 5. doi: http://dx.doi.org/10.2139/ssrn.1012393

Feldman, S. (2003). Enforcing Social Conformity: A Theory of Authoritarianism. Political Psychology, 24(1), 41-74. doi: https://doi.org/10.1111/0162-895X.00316

Holton, A. E., Coddington, M., Lewis, S.C. \& Gil de Zúñiga, H. (2015). Reciprocity and the News: The Role of Personal and Social Media Reciprocity in News Creation and Consumption. International Journal of Communication, 9, 2526-2547.

Ferraro, K. (1995). Fear of Crime: Interpreting Victimization Risk. New York: SUNY Press.

Florack, A., Piontkwoski, U., Rohmann, A., Balzer, T. \& Perzig, S. (2003). Perceived threat and intergroup attitudes of host community members toward immigrant acculturation. Journal of Social Psychology, 143(5), 633-648. doi: https://doi.org/10.1080/00224540309598468

Gonzáles, M. (2002). Aspectos éticos de la investigación. Revista Iberoamericana de Educación, 29, 85-103. doi: https://doi.org/10.35362/rie290952

Guevara, L. (2012). Estereotipos, emociones y tendencia de acción intergrupal en Facebook durante las elecciones generales del 2011 (Unpublished Bachelor's Thesis). Pontificia Universidad Católica del Perú, Lima. Retrieved from http://hdl.handle.net/20.500.12404/4424

Hale, C. (1996). Fear of crime: A review of the literature. International Review of Victimology, 4, 79-150. doi: https://doi.org/10.1177/026975809600400201

Instituto Nacional de Estadística e Informática [INEI]. (2015). Estadística de Seguridad Ciudadana. Retrieved from https://www.inei.gob.pe/media/MenuRecursivo/boletines/boletinseguruidad.pdf

Jost, J., Federico, C. \& Napier, J. (2009). Political Ideology: Its Structure, Functions, and Elective Affinities. Annual Review of Psychology, 60, 307-330. doi: https://doi.org/10.1146/annurev.psych.60.110707.163600 
Lara, T. (2008). La nueva esfera pública. Los medios de comunicación como redes sociales. Retrieved from https://telos.fundaciontelefonica.com/telos/articulocuaderno.asp@idarticulo=9\&rev= 76.htm

Mainwaring, S. (2006). The Crisis of Representation in the Andes. Journal of Democracy, 17(3), 13-27. doi: https://doi.org/10.1353/jod.2006.0048

McCann, S. (1999). Threatening times and fluctuations in American Church Memberships. Personality and Social Psychology Bulletin, 25(3), 325-336. doi: https://doi.org/10.1177/0146167299025003005

McCann, S. (2008). Societal threat, authoritarianism, conservatism and US state death penalty sentencing (1977-2004). Journal of Personality and Social Psychology, 94(5), 913-923. doi: https://doi.org/10.1037/0022-3514.94.5.913

Morales, E. (2004). Internet y Sociedad: relación y compromiso de beneficios colectivos e individuales. Revista Digital Universitaria, 5(8), 2-10.

Oesterreich, D. (2005). Flight into Security: A New Approach and Measure of the Authoritarian Personality. Political Psychology, 26(2), 275-298. doi: https://doi.org/10.1111/j.1467-9221.2005.00418.x

Redondo, S. \& Pueyo, A. (2007). Psicología de la delincuencia. Papeles del Psicólogo, 28(3), 147-156.

Rial, A., Gómez, P., Braña, T., \& Varela, J. (2014). Actitudes, percepciones y uso de Internet y las redes sociales entre los adolescentes de la comunidad gallega (España). Anales de Psicología, 30(2), 642-655.

Rodríguez, L. (2007). La Teoría de la Acción Razonada. Implicaciones para el estudio de las actitudes. Investigación educativa duranguense, (7), 66-77.

Rottenbacher, J. M. \& De la Cruz, M.F. (2012). Ideología política y actitudes hacia la minería en el Perú: entre el crecimiento económico, el respeto por las formas de vida tradicionales y el ambientalismo. Liberabit, 18(1), 83-93.

Ruiz, J. \& Turcios, L. (2009). Percepción de seguridad, victimización y cultura ciudadana: sus relaciones en cinco contextos iberoamericanos. Pensamiento Psicológico, 13(6), 193-202.

Sales, S. M. (1973). Threat as a factor in authoritarianism. Journal of Personality and Social Psychology, 28(1), 44-57. doi: https://doi.org/10.1037/h0035588

Salgado, A. C. (2007). Investigación cualitativa: diseños, evaluación del rigor metodológico y retos. Liberabit, 13(13), 71-78.

Stafford, M., Chandola, T. \& Marmot, M. (2007). Association between Fear of Crime and Mental Health and Physical Functioning. American Journal Public Health, 97(11), 2076-2081. https://doi.org/10.2105/AJPH.2006.097154

Stenner, K. (2005). Cambridge studies in public opinion and political psychology. The authoritarian dynamic. Cambridge University Press. doi: https://doi.org/10.1017/CBO9780511614712

Tyler, T., \& Blader, S. (2003). The Group Engagement Model: Procedural Justice, Social Identity, and Cooperative Behavior. Personality and Social Psychology Review, 7(4), 349-361. doi: https://doi.org/10.1207/S15327957PSPR0704_07 
Vozmediano, L., San Juan, C. \& Vergara, N. (2008). Problemas de Medición del Miedo al Delito. Algunas respuestas teóricas y técnicas. Revista Electrónica de Ciencia Penal y Criminología, 7, 1-17.

Vozmediano, L., San Juan, C. \& Vergara, N. (2009). Miedo al delito en contextos digitales: un estudio con población urbana. Eguzkilore. Cuaderno del Instituto Vasco de Criminología, 23, 175-190.

Authors' participation: a) Conception and design of the work; b) Data acquisition; c) Analysis and interpretation of data; d) Writing of the manuscript; e) Critical review of the manuscript.

J. R. has contributed in a, b, c, d, e; A. E. in a, c, d, e; H. M. L. in c, d, e.

Scientific editor in charge: Dra. Cecilia Cracco. 